donor had no symptoms of the disease when he donated sperm, and his family history provided no obvious indication of any danger.

Instead of waging legal battles, some donor-conceived offspring are taking to the Internet to seek out information about their genetic history. For example, Wendy Kramer of
Boulder, Colorado, who has a son through donated sperm, started an online registry to help connect sperm donors with offspring. So far, the Donor Sibling Registry has attracted more than 25000 members from all around the world and has facilitated 7000 matches.

In the future, suggests Guichon, DOI:10.1503/cmaj.109-3144

\title{
Sperm donor pool shrivels when payments cease
}

Previously published at www.cmaj.ca

$\mathrm{O}$ $\mathrm{n}$ the website privatesperm.com, a 48-year-old civil engineer/ songwriter/composer/music producer named Randy, who describes himself as having genius-level intelligence, offers his sperm to Canadian women who want to have children. But not through artificial insemination. "Natural method only," he writes. On freespermdonor.com, a 53-year-old man who says he is disease-free and has a $\mathrm{PhD}$ offers his sperm to women from any country - as long as they fly to his home in Bahrain, a small country in the Persian Gulf.

Fertility doctors don't recommend that women seeking to conceive take these men - or the increasing number of other men offering free sperm on the Internet - up on their offers. It is not safe, experts say, and these grey-market donors were probably rejected from fertility clinics, which have rigorous screening practices. These websites have been popping up with greater frequency, some fertility experts speculate, because people seeking donor sperm have fewer options than they once did, in large part because many countries no longer pay sperm donors.

In 2006, for instance, the United Kingdom banned payment for sperm, and the number of women using donated sperm fell by more than a quarter. Some UK fertility advocates want payments brought back, claiming that the lack of donor sperm is simply driving women abroad in search of fertility treatments. Some fear that shrinking sperm donor pools could cause too much reliance on a small number of donors, resulting in too

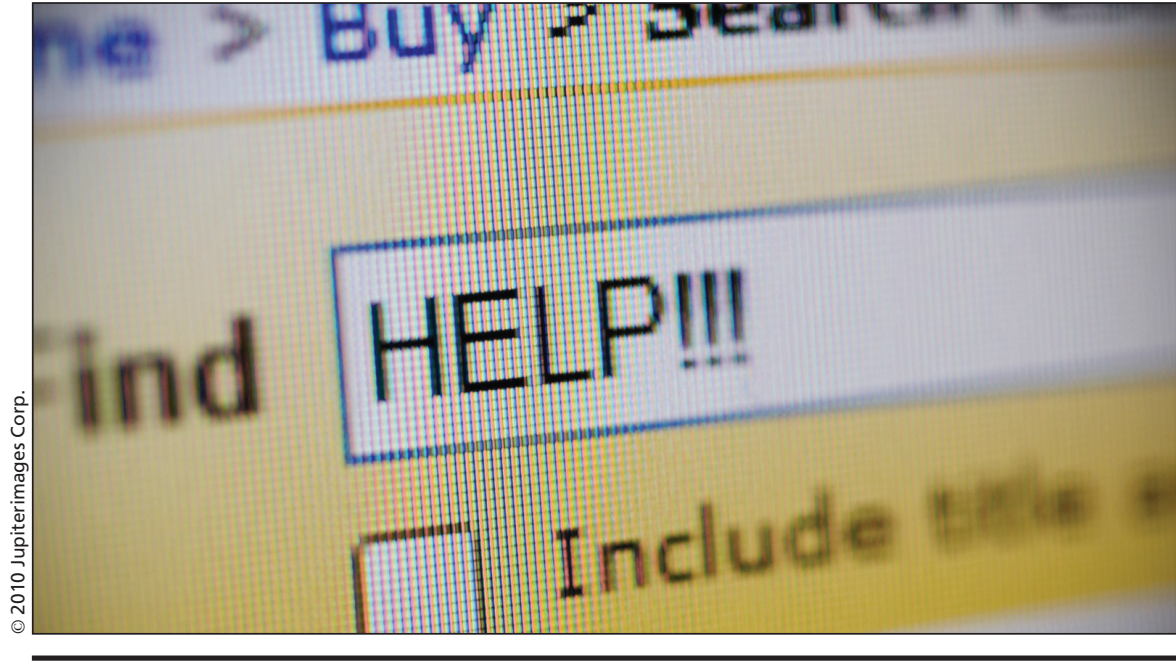

Shrinking donor pools may be leading some fertility clients to look online for private sperm donors, but doctors warn that only fertility clinics screen sperm donors to ensure they are healthy.

many half-siblings growing up in the same area, increasing the risk that blood relatives might unknowing end up in sexual relationships.

In 2004, Canada's Assisted Human Reproductive Act was changed to make it illegal to pay for sperm, the rationale being that sperm should not be considered a commodity. How long did it take for Canada's donor pool to begin shrinking?

"It was immediate," says Dr. Thomas Hannam, who runs the Hannam Fertility Centre in Toronto, Ontario.

Nationwide, there are now between 30 and 70 sperm donors. A person seeking donor sperm from a Canadian of South Asian heritage will have, according to Hannam, only one option. At one time, Canada had more than 40 domestic sperm banks. Now it has only one: The Toronto Institute for Reproductive Medi- cine (ReproMed) in Ontario, which has seen its donor pool shrink dramatically.

"As a Canadian sperm bank, we have experienced a significant decrease in the number of men wishing to become semen donors since 2004 when payments were banned," Dr. Tamer Said, director of the Andrology Laboratory \& Reproductive Tissue Bank at ReproMed, wrote in an email to CMAJ. "We have been fortunate in the last couple of years in finding a limited number of men who are still willing to donate on an altruistic basis, provided that we can cover their expenses associated with donations."

Some countries that have banned payment for sperm have attempted to create a national model based on altruism. Research on sperm donors in Sweden, for example, indicated that most donated sperm because they wanted to help others (Ups J Med Sci 2008;113:305-14). How- 
ever, the country still had a shortage of sperm donors, and many fertility clients sought treatment in other countries.

But if payment is definitely not an option, the altruistic model may be the best alternative, many experts say. According to Hannam, if more resources were put into advertising the cause, sperm donation might become more commonplace, like blood donation is today. "If you normalize it, I expect it would get quite a bit of support," he says.

Said supports the notion that gametes shouldn't be viewed as commercial entities, but he does believe that donors deserve reasonable reimbursement for the expenses they incur during their visits to a sperm bank. "Semen donations are unique; donors have to frequently visit the sperm bank for many months. It is unrealistic to expect that people would be willing to pay out of their pocket to provide donations."

Though Hannam also believes that sperm should not be viewed as a mere commodity, he notes that Canada's nonpayment policy doesn't mean Canadian fertility clients aren't paying for sperm — they just aren't paying for Canadian sperm. About $80 \%$ of the donor sperm used in Canada comes from the United States, where donors are paid.

"It has set us up to rely on American importers," says Hannam. "That is fine, if you believe paying people for their sperm is fine."

The donor shortage that has resulted since payment was banned has limited the choices available to Canadian fertility clients. Couples seeking treatment generally prefer to have children with certain traits - height, hair colour, skin colour — similar to their own. Today, Canadian clients will typically have a choice of only three donors who meet their criteria. This lack of variety may be one reason people might consider looking online for sperm, though Hannam says that would be unwise, for several reasons.

"The obvious one is health," he says. "The screening for sperm donors at clinics is rigorous, to say the least, and that is to protect patients. The one people may not be aware of is the emotional risk. There is so much room for exploitation." - Roger Collier, CMAJ

DOI:10.1503/cmaj.109-3152

\section{More news at www.cmaj.ca}

Concerns raised about Ontario's new regime for bariatric surgery: The province of Ontario's move to reduce costs by expanding domestic capacity to perform bariatric surgery is raising concerns about longer waiting lists and regional variations in the availability of surgery. - Becky Rynor, Ottawa, Ont.

Ontario hospitals says service, staff or program cuts may be inevitable: The regional health authorities that govern Ontario hospital budgets are bracing for service and staffing cuts after the province announced that funding will at best rise by 2\% for fiscal year 2010/11. — Laura Eggertson, Ottawa, Ont.

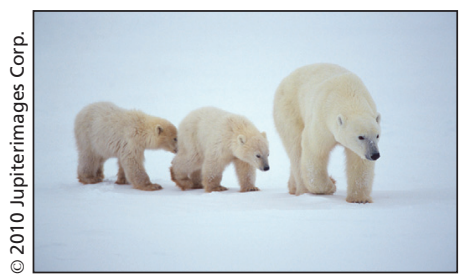

New Inuit centre hopes to influence research agenda: Inuit Tapiriit Kanatami has established an Inuit Knowledge Centre in Ottawa, Ontario, to close the research gap involving the Inuit and Canada's Arctic. - Laura Eggertson, Ottawa, Ont.

Hazards on the homestretch in Washington's push to extend health care to millions: United States legislators face the messy task of reconciling conflicting health reform legislation passed by the House of Representatives and the Senate. - Cal Woodward, Washington, DC

The rise of drug-resistant strains of HIV in Africa: Funding cuts for antiretrovirals for HIV patients in Africa and a tendency of many patients to take the drugs intermittently is driving fears that drug-resistant strains of HIV will reemerge. - Wendy Glauser, Zomba, Malawi, and Ben Simon, Kampala, Uganda

Medical schools continue to tighten noose on faculty with conflicts of interest: The arsenal of tools being used to promote greater disclosure of conflicts of interest by medical faculty continues to expand. - Andrea Ozretic, Ottawa, Ont., and Roger Collier, CMAJ

US doctors divided over health reforms: America's two most influential medical associations are deeply divided over the merits of changes respectively proposed by the House of Representatives and Senate. - Paul Christopher Webster, Toronto, Ont.

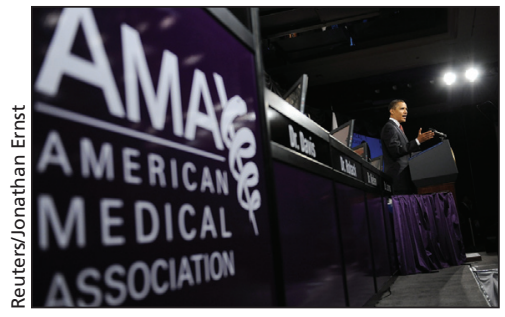

Nova Scotia hospital buys bulletproof vests: Security staff at a children's hospital in Nova Scotia will soon be equipped with bulletproof vests. donalee Moulton, Halifax, NS

To mandatory nap or not to mandatory nap: While the United States Institute of Medicine is urging that a five-hour snooze should be made mandatory for all medical interns and residents who are putting in 16 hours of work in a row, Canadians appear unconvinced - Sabrina Doyle, Ottawa, Ont.

DOI:10.1503/cmaj.109-3156 cmaj.ca 